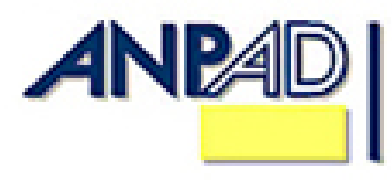

Available online at http://www.anpad.org.br/bar

BAR, Rio de Janeiro, v. 10, n. 2, art. 6, pp. 219-238, Apr./June 2013

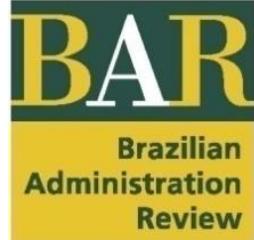

$($ co) 1

\title{
A Perceived-Control Based Model to Understanding the Effects of Co-Production on Satisfaction
}

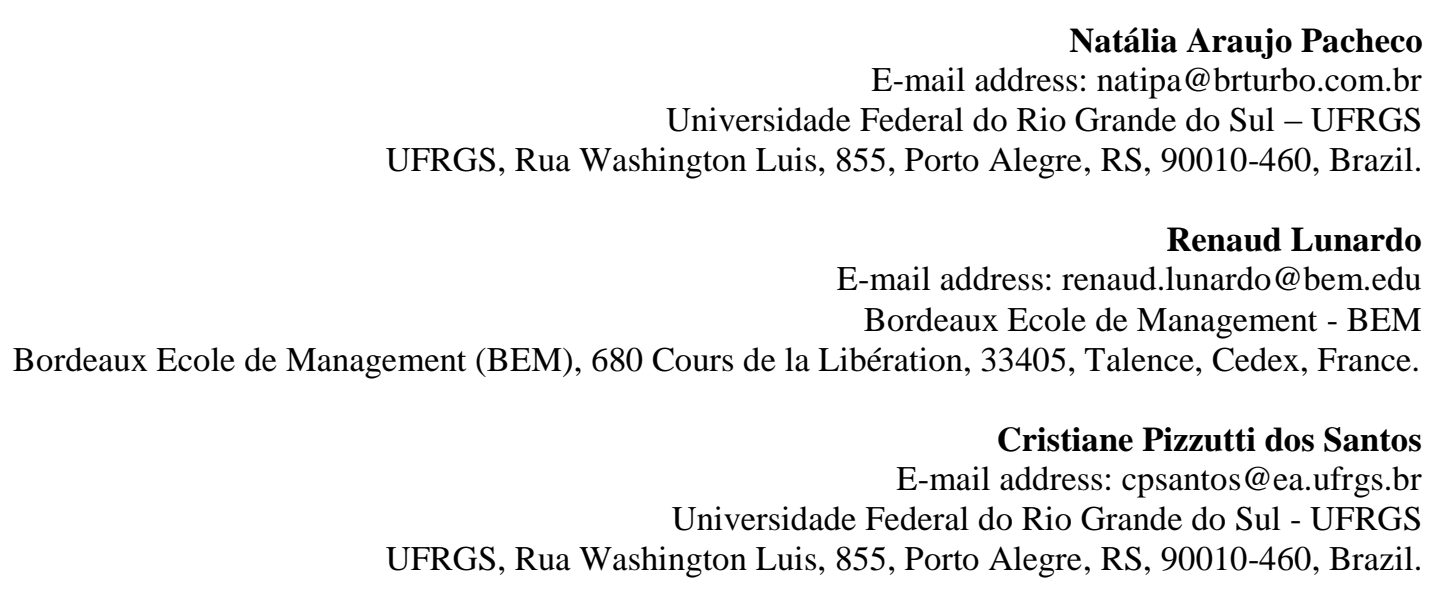

Received 11 May 2012; received in revised form 15 November 2012; accepted 21 February 2013; published online $1^{\text {st }}$ April 2013. 


\begin{abstract}
This article represents an initial effort to analyze the complex linkages among co-production, perceived control and satisfaction. Co-production refers to the consumer participation in production activities and is here considered a proxy for behavioral control as it allows consumers to have some control over the process of the desired product or service. Considering the increase of co-production in consumption activities, understanding the linkage between the control from the co-production process and the satisfaction toward the related consumption may be quite useful to firms interested in adopting such a managerial tool. Two experimental studies - one in a service setting and the other in a product setting - show that co-production positively affects customer's satisfaction through the mediating effect of perceived control. Information gain and refund choice, representing cognitive and decisional controls respectively, also enhance customers' perceived control.
\end{abstract}

Key words: co-production; perceived control; information; refund choice; satisfaction. 


\section{Introduction}

Consumer participation through co-production is increasingly present in recent marketing literature (e.g., Dong, Evans, \& Zou, 2011; Hunt, Oneto, \& Varca, 2010; Troye \& Supphellen, 2012). From the company perspective, co-production can be an effective marketing tool, the interaction between customer and firm being pointed out as a source of value creation (Prahalad \& Ramaswamy, 2004; Wikström, 1996) and competitive effectiveness (Bendapudi \& Leone, 2003) which may positively influence consumers' perception of quality (Golder, Mitra, \& Moorman, 2012). From the consumer perspective, co-production may be of interest since it allows them to perceive some control over the process of the desired product or service (Etgar, 2008).

The perceived control concept rests on research in both social (Averill, 1973; Skinner, 1996) and environmental (Mehrabian \& Russell, 1974) psychologies. Distinct from the general Locus of Control concept that refers to a general degree to which individuals believe that they have control over events in their lives (Rotter, 1966), perceived control refers to a more situational perceived ability to significantly alter a situation (Burger, 1989; Thompson, 1981). Such control has been showed to exert a crucial role in people's lives by exhibiting stress-reducing (Glass \& Singer, 1972; Lazarus \& Folkman, 1984) and motivation-inducing (Kidwell \& Jewell 2010; Skinner, 1995; Sprott, Brumbaugh, \& Miyazaki, 2001) properties. Having made its first appearance in consumer research only in the 1990s (Hui \& Bateson, 1991), perceived control has been found to exert positive influence on pleasure (Hui \& Bateson 1991), mood, involvement (Ward \& Barnes 2001), satisfaction (Wathieu et al., 2002) and intention to behave (Mathur, 1998). However, despite the increase of co-production in consumption activities, a clear need remains to understand the linkage between the control that stems from the co-creation process and the satisfaction toward the consumption (Lusch \& Vargo, 2006). More specifically, a question remains unanswered: does co-production lead to higher consumer satisfaction by making them feel more in control? In other words, it still has to be determined whether co-production enhances consumers' satisfaction through the control they feel during the purchase.

To answer this question, the conceptualization of control is discussed first. Indeed, a wide set of different terms, signifying essentially the same thing, have been used to define perceived control in consumer research. As emphasized by Rodin (1990), the perceived control construct has been called by "many different things, including, besides control, self-directedness, choice, decision freedom, agency, mastery, autonomy, self-efficacy, and self-determination" (Rodin 1990, p. 1). Meanwhile, as the definition has broadened, the precision of the meaning has lessened, leading to a surprising heterogeneity among the constructs researchers use to describe perceived control. For instance, researchers in retailing often refer to an environmental approach that views control as the emotion of dominance (Hui \& Bateson, 1991; Lunardo \& Mbengue, 2009; Mehrabian \& Russell, 1974; Rompay, Galetzka, Pruyn, \& Garcia, 2008; Ward \& Barnes, 2001), while others retain a general definition in which the construct refers to the belief that one can influence one's environment and/or bring about desired outcomes (Van Raaij \& Pruyn, 1998).

To progress in the use of a precise definition of control, this research relies on Skinner's (1996) conceptualization, which includes behavioral, cognitive, and decisional controls as antecedents of perceived control. Also, to answer the question addressing the role of control as the underlying mechanism explaining the positive influence co-production has on satisfaction, we consider the close definitions of behavioral control - as the ability to exert a direct influence or action on the environment - and co-production to use the latter as a proxy for behavioral control and to test its influence on perceived control and consequently on satisfaction. Sticking to Skinner's (1996) conceptualization, we also consider the definition of cognitive control as the subject's interpretation and appraisal of an event, and the widely acknowledged role information has in such an interpretation (e.g., Burger \& Arkin, 1980; Faranda, 2001; Langer \& Saegert, 1977), to include information as a proxy for cognitive control in our framework. We also rely on the definition of decisional control as the opportunity to choose among different courses of action, and the wide body of literature emphasizing the role choice has in decisional control (e.g., Hui \& Bateson, 1991) in order to use 
refund choice as a proxy for decisional control. The resulting framework enables the authors to better explain the relationship between co-production, perceived control and satisfaction, as well as the potential mediating role of co-production on satisfaction, which was proposed by Ertimur (2008) but has not yet been empirically tested. In other words, it posits that co-production enhances consumer satisfaction through the control it makes them feel during purchasing.

Although perceived control is a well-known construct that has been studied in several contexts, co-production is a newer construct that only a few years ago was diagnosed as lacking empirical investigation (Meuter, Bitner, Ostrom, \& Brown, 2005). This research ${ }^{(1)}$ adds to the recent growing coproduction investigation and literature by addressing the mediating role perceived control holds in the relationship between co-production and satisfaction. This paper is organized as follows. After reviewing extant research on co-production and perceived control, we propose a perceived controlbased framework of the effects co-production has on satisfaction. Based on Averill (1973) and Skinner's (1996) discussion on control conceptualization, this model includes behavioral, cognitive and decisional controls, which correspond respectively to co-production, information and refund choice. Supporting results from two experimental studies are then presented. Study 1 investigates the effects of co-production and information, representing behavioral and cognitive controls, respectively, on consumer's feelings of control and satisfaction. Study 2 focuses on the effects of co-production and refund choice, which represent behavioral and decisional controls, respectively, on the same output. These two studies support the mediating role control holds in the relationship between co-production and satisfaction. It also gives support for the tridimensional model and thus the use of a more complex conceptualization of control in consumer research. In the last section, key findings and their implications for theory and practice are discussed.

\section{Co-Production: an Antecedent of Perceived Control in Addition of Information and Choice}

Co-production has been defined as requiring consumer participation in production activities, such as product design, resource aggregation and other processing activities leading to an output (product or service) that will be used or consumed (Etgar, 2008). The importance consumer participation has in a co-production context is such that the product or service cannot be created apart from the customer's active participation (Bitner, Faranda, Hubbert, \& Zeithaml, 1997). Although coproduction is directly linked to customization (Etgar, 2008), these two constructs differ. Co-production allows consumers to really take part in creation, execution and delivery of a product or service, while customization implies gathering information about consumers' preferences to offer them a suitable product (Peppers \& Rogers, 1993) or even to give them a menu of items they can choose to tailor an appropriate product to their needs (Dellaert \& Dabholkar, 2009; Liechty, Ramaswamy, \& Cohen, 2001).

The question regarding whether such participative strategies may lead consumers to perceive more control has received little attention to date. However, there would be a difference in the amount of control consumers assume in each one of these strategies (Ertimur, 2008). In fact, one may argue that co-production would be the strategy which provides a higher level of control. For instance, in a study conducted by Bateson and Langeard (1982) to understand how people evaluate and choose services between more participative services (e.g., pump your own gas in a service station) and a less participative one (e.g., have an attendant pump the gas for you), control was, among seven dimensions, the one that stood out in importance. Consumers who chose the more participative scenario perceived control as important, while people from the less participative group reported risk as an important dimension. Consumers who chose more participative services also perceived less control in the traditional and less participative services. Thus, this indicates a positive relationship between coproduction and perceived control. 
More specifically, such a relationship may find theoretical support in the conceptualization of control proposed by Averill (1973) and discussed by Skinner (1996). These two authors distinguish behavioral, cognitive, and decisional controls. These forms of control have received significant attention. This is especially true for behavioral control, which was included in the Theory of Planned Behavior (Ajzen, 1991, 2002) to explain intention and behavior in a wide range of consumption settings, from using e-coupons (Kang, Hahn, Fortin, Hyun, \& Eom, 2006) to mobile services (Nysveen, Pedersen, \& Thorbjornsen, 2005) or new technology-based self-service options (Dabholkar, 1996). However, while behavioral, cognitive, and decisional controls are defined as kinds of control in Averill's (1973) typology, Skinner (1996) argued that they should rather be seen as potential means or modes of control, making behavioral, cognitive, and decisional controls antecedents of the more general construct of perceived control. According to this latter conceptualization, the behavioral control, which represents the availability of a response which may directly influence the objective characteristics of a situation, may thus be considered as an antecedent of perceived control. Since coproduction implies such a direct influence from a consumer on the performance of the production process (Etgar, 2008), co-production may also be considered as a behavioral antecedent of perceived control. Thus, the following hypothesis is proposed:

H1: Consumers who co-produce perceive greater control when compared to those who do not.

After establishing the linkage between co-production and perceived control, information, as a potential cognitive antecedent of perceived control, is analyzed. As marketing has evolved from a market to to a market with philosophy in which consumers collaborate with the value creation process (Lusch, Vargo, \& O'Brien, 2007), it becomes even more important to consumers that they can access the information they need in order to do so. In fact, according to Dholakia, Zwick, and DenegriKnott (2010), information dominates value co-creation, which, according to Vargo and Lusch (2008), refers to the value created collaboratively by firm and customer that may involve co-production or not. Averill (1973) pointed to information gain as one kind of cognitive control. Although some may say information is not necessarily a type of control, it may engender feelings of control (Thompson, 1981). Since it leads to predictability, and the ability to predict the consequences of an event may induce feelings of control (Staub, Tursky, \& Schwartz, 1971), information gain may also be seen as a way to achieve foreknowledge and, therefore, seen as an antecedent of perceived control (Wortman, 1975). In consumer research, the effect of predictability on perceived control has been emphasized by Holt (1995), who showed through an analysis of extensive observations of baseball spectators that their feeling of being able to predict action on the field enhanced the perception that they are involved in the game's production and thus how they interject some control over the game. In the context of service encounters, predictability can offer cognitive control to customers and service providers, even though they have little direct control over the situation (Bateson, 1985). For example, a study by Langer and Saegert (1977) indicated that averseness to crowding in a supermarket could be significantly ameliorated by information that gave individuals cognitive control of the situation and the ability to behave adaptively, by leaving the store for instance. The preceding discussion suggests the following hypothesis:

H2: Consumers who gain more information perceive greater control when compared to those who gain less information.

Choice has been highlighted as something desirable in consumer behavior literature, being positively associated with increases in satisfaction (Botti \& McGill, 2006). Choice restriction is associated with negative emotional responses, including anger, resentment, and depression, as well as with negative behavioral responses like rejection and rebellion (Botti et al., 2008). The linkage between choice and perceived control has been widely emphasized in the literature, ever since Averill (1973) referred to choice as a decisional type of control. The effects choice has on perceived control can also be explained by DeCharms's theory of personal causation (1968). According to this theory, individuals who perceive their behavior as stemming from their own choices will perceive more control and in turn will be more highly task motivated than individuals who see their behavior as stemming from external force. Such assumption that consumer choice may result in increased consumer perceived control was supported for service encounters by Hui and Bateson (1991) and in 
service recovery by Chang (2008). Even when dealing with illusion of control instead of true control, Langer (1975) found similar results. Giving an individual the opportunity to choose made him/her feel greater control even though he/she participated in a pure chance task. Based on these results, consumers who have a choice perceive greater control than those who do not have it. Note that each of the aforementioned studies refers to a different way of giving participants a choice; such as, giving participants the opportunity to choose whether they stay somewhere or come back later (Hui \& Bateson, 1991), which recovery service option they want (Chang, 2008), and which lottery ticket they want (Langer, 1975). The choice participants receive in this study is the one of returning a product and asking for a refund, because this choice suits a co-production context better than the other choices presented in the literature review. The following hypothesis is proposed:

H3: Consumers who have refund choice perceive greater control when compared to those who have no refund choice.

\section{Perceived control and satisfaction in the co-production context}

To understand how the perception of control influences the satisfaction process is of interest because of the importance satisfaction has in predicting a consumer's future choices (Woodruff, Cadotte, \& Jenkins, 1983). Within this perspective, understanding whether and how co-production may contribute to enhance customers' perceived control and consequently satisfaction appears also relevant.

The positive effect of perceived control on satisfaction has received much support from the literature in various streams of research. For instance, increased control has been related to more satisfaction in the work context (Greenberger, Strasser, Cummings, \& Dunhan, 1989). In a salesperson-supervisor relationship context, Oliver and Anderson (1994) and Challagalla and Shervani (1996) concluded that employees who feel in control (i.e., who possess the set of skills and abilities that enables good performance) exhibit more satisfaction. In a retail setting, Rompay, Galetzka, Pruyn, and Garcia (2008) suggested that when a consumer's perceived control is reduced through the restriction of free movement throughout the store, such a reduction in control may negatively affect shopping satisfaction. Referring to service recovery context, Chang (2008) found a positive relationship between increases in perceived control and increases in customer satisfaction with recovery efforts. In the context of hospitality services, Namasivayam and Hinkin (2003) and Namasivayam (2004) examined the effect of perceived control on service encounter satisfaction in a restaurant and a hotel setting. Collier and Sherrell (2010) found a positive effect between control and satisfaction mediated by speed of transaction, exploration, and trust in the service provider in the context of self-service technology. Lee (2012) investigated the relationship between behavioral, cognitive, and decisional control on medical service users' dissatisfaction. Although the way the scales were presented may raise some doubt as to whether it appropriately represents Averill's (1973) control typology, the findings show the lower the perception of cognitive and decisional control, the greater the dissatisfaction with medical service. The results highlight the importance of control: individuals perceiving higher levels of control are more satisfied.

More specifically regarding the linkage between co-production, perceived control and satisfaction, Bitner, Faranda, Hubbert, and Zeithaml (1997) suggested that co-production may increase consumer satisfaction. Concerning the process by which co-production may increase satisfaction, Ertimur (2008) made the interesting proposition that offering consumers the option to co-produce may increase their perception of decisional control, while the co-production itself may increase behavioral control, which will positively affect a customer's process satisfaction. Based on an empirical work, Hunt, Oneto and Varca (2010) found higher satisfaction among consumers engaged in co-production. Similarly, Dong, Evans and Zou (2011) found a positive relationship between co-production in service recovery and satisfaction, while Troye and Supphellen (2012) found that co-production positively influences consumers' evaluation of an outcome, corroborating Golder, Mitra and Moorman (2012) who argue that co-production positively influence consumer's quality evaluation of a product's and its attributes' performance. These linkages, first between co-production and perceived control, second 
between control and satisfaction, and finally between co-production and satisfaction, are important to understanding how perceived control works in a co-production context. We propose here that the effect co-production has on satisfaction is mediated by consumers' perceived control. Thus, the effect of co-production on satisfaction may become insignificant or at least less significant when perceived control is included in the model. Therefore, the two following hypotheses are proposed:

H4: The greater the control perceived by customers, the greater their satisfaction.

H5: The effect of co-production on customers' satisfaction is mediated by their perceived control.

It is important to note that different types of control may interact in a complex way (Cornelius $\&$ Averill, 1980). However, so far the literature on these interactions does not provide a consistent theoretical base for the development of hypotheses. For example, Cornelius and Averill (1980) found a significant interaction between behavioral and cognitive controls, but did not find an interaction between behavioral and decisional controls. On the other hand, Witt, Andrews and Kacmar (2000) found that, in an organizational setting, the presence of policies that give less behavioral control to employees reduces employees' satisfaction at a lesser degree when the employees have more decisional control; i.e., when they participate more in decision processes with their supervisors. Hence, because the literature is still inconsistent on the interactions among the different types of control, we treat the test of these effects as an empirical issue in this article (i.e., as an exploratory investigation, with no formal hypotheses).

Thus far, general conceptualization for perceived control, its antecedents and its mediating role have been presented. The theoretical framework under investigation is available in figure 1. Following Averill and Skinner's conceptualization of control, what is proposed here is that co-production, in addition to information and refund choice, influences consumers' perception of control, which in turn influences satisfaction. The remainder of the current work is organized as follows: the first experiment simulates behavioral and cognitive controls, respectively, through co-production and information, to examine them as two possible sources of perceived control and satisfaction. The second experiment replicates Study 1 by replacing information with refund choice. Behavioral and decisional controls are simulated, respectively, through co-production and choice and their effects on perceived control and satisfaction are tested.



Figure 1. Theoretical Framework. 


\section{Study 1}

\section{Design and procedure}

A 2 (co-production: co-production and no co-production) x 2 (information gain level: high and low) factorial design was employed in the first study. Subjects were undergraduate students $(n=97)$ of a business program at a major Brazilian University, all of whom voluntarily participated. One of the researchers went to classes (with prior permission from instructors) and students were invited to participate in the study, answering a paper-and-pencil questionnaire. No incentive was given to them. The decision of having those undergraduate students as a sample is due to their relative schooling and income homogeneity, which allows the formulation of scenario descriptions both comprehensible and affordable for the sample subjects. Subjects were informed that the objective of the research was to investigate college students' perceptions of their experiences in purchasing various service categories. The participants were randomly assigned to one of the four scenarios. Data was collected by one of the authors in December 2010.

Participants received a questionnaire with the following narrative: After a tough semester at the university, you decided to travel on vacation and you go to a travel agency to look at the possibilities. The narrative sequence then varied to manipulate co-production and information level. Participants who were randomly assigned to a co-production scenario read that the following text: When you arrive at the agency, the agent explains you can design your own trip itinerary, so your travel will have the exact features you want. Note that this is a typical co-production scenario and not a mere customization situation as it allows the consumer to freely participate in the production process instead of giving them a limited choice set defined by the firm, which is typical in the case of customization (Dellaert \& Dabholkar, 2009; Liechty et al., 2001). Participants in the non co-production condition were provided the text: When you arrive at the agency, the agent explains he can offer you three package options and that it is not possible to design a different package.

Low information scenarios presented the text: The agent gives you price information. No other information is offered to you, and high information scenarios provided the text: The agent gives you a booklet where you find information about each city of this country's region, such as tourist points, cultural events and celebrations. You also receive information about hotels, hostels and restaurants. The agent gives you price information.

Before applying the experiment, the authors carefully pretested the scenarios with 89 students to measure whether they believed the situation was possible, to check the efficacy of the manipulations, and the reliability of the scales. The results of this pilot test revealed a great belief that the situations described in the scenarios could happen $(M=5.26$, on a seven-point scale, where $1=\mathrm{It}$ is impossible and $7=$ It is possible), which was significantly different from the scale's midpoint $(p<.001)$. Perceived control and satisfaction scales showed good reliability indices $(\alpha$ of .95 and .97, respectively). Based on this pilot study few changes were made in the scenarios to improve the manipulations. The authors also performed a qualitative pretest with ten students to investigate their opinion of the scenarios, mainly concerning familiarity and realism, whether the language used was appropriate, whether the questions were clear, and the possibility of demand artifacts, which is when participants behave in a way to confirm or reject a hypothesis they think is the research objective (Sawyer, 1975). Overall, the respondents did not know the real objective of this research and reported they had already experienced a situation similar to the one described or at least had known a person who had.

\section{Measures}

Perceived control was measured following the procedure found in Hui and Bateson (1991) and Rompay et al. (2008), adapted to the research context. The four items of the dominance scale (Mehrabian \& Russell, 1974) from Rompay et al. (2008) were adapted to this study (e.g., In this 
agency, I felt in control of the situation). Three other items from Bateson and Hui (1992) were used (e.g., In this agency, I would feel able to influence the way things were). The two subscales were then aggregated to measure perceived control $(\alpha=0.95)$, following Hui and Bateson (1991) and Rompay et al. (2008) who also used two perceived control scales.

Satisfaction was measured using a three item scale $(\alpha=0.94)$ based on Verhoef (2003), where participants rated their satisfaction with the travel agency, the purchase and the purchase process. Three questions were used to conduct manipulation checks, one about co-production (I have helped design the trip I have bought) and two about information gain levels (Regarding the amount of information given by the travel agency, I consider it was: insufficient/sufficient; low information level/high information level).

All the statements were rated on seven-point scales $(1=$ strongly disagree, $7=$ strongly agree $)$.

\section{Manipulation checks}

ANOVA and Chi-Square analyses were conducted to ensure that the experimental cells did not differ in terms of respondents' profiles. Results revealed that the cells did not differ, neither in terms of respondents' age $(F(3,90)=1627 ., p>.05)$, nor in terms of gender $\left(\chi^{2}=7.665, d f=3, p>.05\right)$.

The manipulation of co-production and information were tested by a 2 × 2 ANOVA. Participants' estimates of co-production were higher in co-production scenarios $\left(M_{\text {copr }}=5.72\right)$ than in no co-production scenarios $\left(M_{\text {nocopr }}=3.00 ; F(1,93)=59.37, p<.001\right)$. There were no other significant treatment effects on this measure, indicating that co-production manipulation was successful.

Also, participants' perceptions of information were greater in the high information condition than in the low information condition $\left(M_{\text {high }}=5.45\right.$ vs. $\left.M_{\text {low }}=2.50 ; F(1,93)=85.55, p<.001\right)$. No other significant treatment effects were found on this measure, indicating that information manipulation was effective.

\section{The effects of co-production and information}

The ANOVA revealed significant main effects of both co-production $(F(1,93)=57.48, p$ $<.001)$ and information $(F(1,93)=13.53, p<.001)$ on perceived control. Perceived control was greater on co-production scenarios $(M=4.32)$ when compared to non co-production scenarios $(M=$ 2.54). Participants with high information level reported greater perceived control $\left(M_{\text {high }}=3.87\right)$ than respondents with low information $\left(M_{\text {low }}=3.02\right)$. These results supported Hypotheses 1 and 2 . There was no significant interaction effect from independent variables over perceived control $(p>.05)$. Linear regression showed that perceived control has a significant impact on satisfaction $(\beta=.809$, $t(95)=13.39, p<.001)$, offering support for Hypothesis 4 .

\section{The mediating role of perceived control}

A primary goal of this study was to examine a potential underlying mechanism that might account for the effect of co-production on satisfaction. Thus, perceived control was tested as a potential mediator of this effect. Baron and Kenny's (1986) procedure has been widely used to test mediation, this procedure assumes the existence of a direct effect between the independent variable and the dependent variable. However, Zhao, Lynch and Chen (2010, p. 204) have recently discussed such an assumption and proposed that "to establish mediation, all that matters is that the indirect effect is significant". We followed their procedure in this research. As recommended, Preacher and Hayes' (2008) macro and 5000 bootstrapped samples were used to determine whether the indirect effect is significant. The bootstrapping procedure has been used to counteract the assumption of normality of the sampling distribution of the indirect effect $(a b)$ which is required by the Sobel test (Hayes, 2009). 
For each mediation analysis, the independent variable was dummy coded, that is, the coproduction condition was coded 1 , while the lack of co-production condition was coded 0 , so that a positive effect of the independent variable on the mediator in the indirect path can be interpreted as the effect of the co-production and a negative effect as the one caused by its absence. Results show that the indirect effect of co-production was significant $(\mathrm{a} \times \mathrm{b}=1.53 ; p<.001)$ suggesting that mediation is established (Zhao, Lynch, \& Chen, 2010) and supporting Hypothesis 5. In the indirect path, coproduction increases perceived control by $\mathrm{a}=1.78 ; \mathrm{b}=.86$, so in the co-production situation, a unit increase in perceived control increases satisfaction by .86 units. The direct effect of co-production on satisfaction ( $\mathrm{c}$ in the Figure 1 ) is not significant $(\mathrm{c}=-.08 ; p>.10)$, leading to conclude an indirect-only mediation of perceived control. Using 5000 bootstrap samples, this analysis revealed a significant indirect effect of co-production on satisfaction through perceived control, with a $95 \%$ bias corrected and accelerated confidence interval excluding zero (1.08 to 2.02). These results indicate indirect-only mediation (Zhao et al., 2010) - what Baron and Kenny (1986) refer to as full mediation - in which omitted mediators are unlikely. Results are summarized in Figure 2.

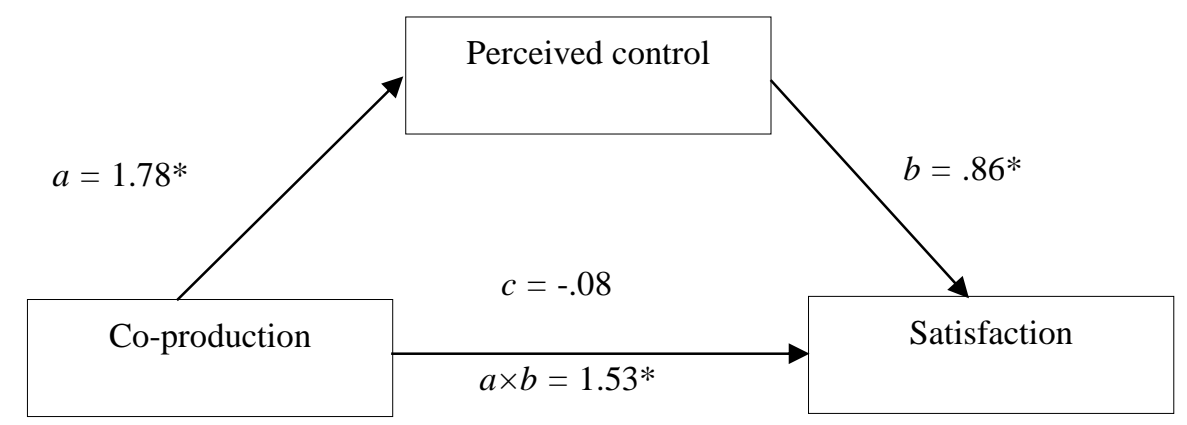

Figure 2. The Mediating Role of Perceived Control in the Effect of Co-Production on Satisfaction. These are unstandardized coefficients.

$* p<.001$.

\section{Discussion}

Results of study 1 show that both co-production and information enhance consumers' perceived control, which in turn affects satisfaction. Results of the mediation test also show that perceived control fully mediates the effect of co-production on satisfaction. Study 2 extends the results of the first study to the context of co-production and refund choice. What is predicted in it is that coproduction and choice lead to more perceived control and outcome satisfaction, with a mediating role of perceived control. This time, these relationships are tested in a context of co-production of goods, maintaining the same kind of sample, undergraduate students, but collecting data in a different country to enhance the external validity of the research.

\section{Study 2}

\section{Design and procedure}

Participants in this 2 (co-production: co-production and no co-production) $\times 2$ (consumer choice: choice of refund and no choice of refund) factorial design between-subjects experiment were 91 undergraduate students of the business course from a major French University. Similar to Study 1, one of the researchers went to classes and students were given the option to participate in the study, answering a paper-and-pencil questionnaire. No incentive was given to them. Subjects were informed that the objective of the research was to investigate college students' perceptions of their experiences 
in purchasing various product categories. They were randomly assigned to one of the four cells of the experimental design. Data was collected by one of the authors in January 2011.

Participants received the following narrative: You have bought a computer to perform your personal and professional activities and now you need a desk on which you can use it. You go to a store to look at some desks that are displayed. Participants who were randomly assigned to a coproduction scenario could subsequently read the text: You ask the salesperson if you could design your own desk. The salesperson says that it is possible and calls an employee that promptly starts to draw your writing desk following your instructions. This way, your desk will have the features (height, width, divisions, accessories, etc.) you want. As in experiment 1, the co-production scenario allows consumer to participate in the production process without a pre-defined choice menu as in a customization process. Participants assigned to a non co-production scenario received a different text: You ask the salesperson if you could design your own desk. The salesperson says that it is not possible, because the factory can only produce desks identical to those displayed in the store. So you keep looking at the models in the store.

In order to manipulate customer choice, two different texts were given to participants, one narrative that contained the refund choice: The salesperson informs you that the store has a satisfaction guarantee policy, which offers a full refund in case of returning the product, and another one that did not present a refund choice: The salesperson informs you that the store doesn't have a satisfaction guarantee policy, which means you will not get a refund in case of returning the product. All students, independent of the scenario assigned, were told that they made the purchase.

\section{Measures}

The same scales from study 1 were used to assess respondents' perceived control $(\alpha=.90)$, and satisfaction $(\alpha=.93)$. Two questions were used, one about co-production (I have helped design the desk I have bought) and one about choice (The store offers me the possibility to get a refund in case I am not satisfied) to check the manipulations. agree).

Again, all the statements were rated on seven-point scales $(1=$ strongly disagree, $7=$ strongly

\section{Manipulation checks}

As done for study 1, ANOVA and Chi-Square analyses were run to ensure that the experimental cells did not differ in terms of respondents' profiles. As in Study 1, results revealed that the cells did not differ, neither in terms of respondents' age $(F(3,86)=.939, p>.05)$, nor in terms of gender $\left(\chi^{2}=5.405, d f=3, p>.05\right)$.

Both manipulations were effective. Participants' estimates of co-production were higher in coproduction scenarios $\left(M_{\text {copr }}=5.98\right)$ than in non co-production scenarios $\left(M_{\text {nocopr }}=1.41 ; F(1,86)=\right.$ 455.12, $p<.001$ ). No other significant effect was found. Correspondingly, participants' perception of refund choice were greater in the choice condition than in the no-choice condition $\left(M_{\text {choice }}=6.09 \mathrm{vs}\right.$. $\left.M_{\text {nochoice }}=1.98 ; F(1,86)=151.21, p<.001\right)$. There were no other treatment effects on this measure.

\section{The effects of co-production and choice}

ANOVA revealed a significant main effect of both co-production $(F(1,86)=110.20, p<.001)$ and refund choice $(F(1,86)=23.34, p<.001)$ on perceived control. As predicted, perceived control was greater on co-production scenarios $\left(M_{\text {copr }}=4.99\right)$ when compared to non co-production scenarios $\left(M_{n o c o p r}=3.05\right)$. Participants who had refund choice reported greater perceived control $\left(M_{c h}=4.42\right)$ than respondents without it $\left(M_{\text {noch }}=3.64\right)$. These results support Hypotheses 1 and 3 . As in study 1 , there was no significant interaction effect from independent variables over perceived control $(p>.05)$. 
Linear regressions indicated a significant effect of perceived control $(\beta=.872, t(88)=16.72, p<.001)$ on satisfaction, supporting Hypothesis 4.

\section{The mediating role of perceived control}

The same procedure from Study 1 was used to test the mediating effect of perceived control on the relationship between co-production and satisfaction. Results show that the indirect effect of coproduction was significant $(\mathrm{a} \times \mathrm{b}=1.65 ; p<.001)$ suggesting that mediation is established (Zhao et $a l ., 2010)$. In the indirect path, co-production increases perceived control by a $=.1 .94 ; b=.85$, so maintaining the situation of co-production, an increase of one unit in perceived control increases satisfaction by .85 units. However, while Study 1 revealed a lack of significance of the direct effect c, the results of Study 2 revealed a significant direct effect of co-production on satisfaction $(c=.79 ; p$ $<.001)$. As recommended by Zhao et al. (2010), the type of mediation can be identified through the sign of $a \times b \times c$. As this sign is positive here, the mediation refers to what Zhao et al. (2010) call a complementary mediation, in which the mediated effect $(\mathrm{a} \times \mathrm{b})$ and the direct effect $(\mathrm{c})$ both exist and point at the same direction. Using 5000 bootstrap samples, this analysis revealed a significant indirect effect of co-production on satisfaction through perceived control, with a 95\% bias corrected and accelerated confidence interval excluding zero (1.21 to 2.12). Such a type of mediation overlaps with Baron and Kenny's (1986) partial mediation. Results of the mediation analysis are summarized in Figure 3.

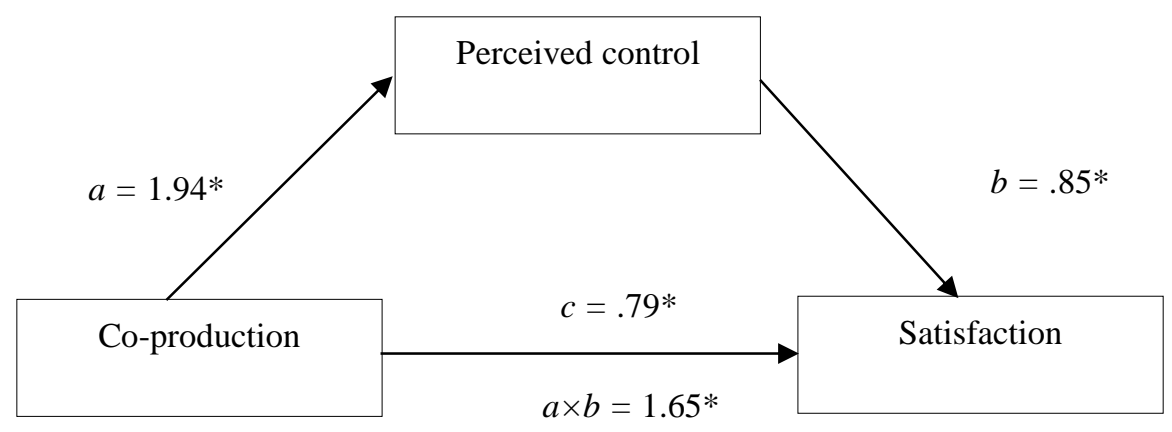

Figure 3. The Mediating Role of Perceived Control in the Effect of Co-Production on Satisfaction. Note: These are unstandardized coefficients. $* p<.001$.

\section{Discussion}

Results of Study 2 supported the hypothesized positive effects of co-production and refund choice on perceived control, and of control on satisfaction. The result showing that choice leads to more perceived control is consistent with literature suggesting that having choice among alternatives leads consumers to perceive a greater sense of ownership of decision consequences and thus a greater feeling of control (Botti \& McGill, 2006). Findings of the mediation test show that perceived control partially mediates the effect of co-production on satisfaction.

\section{General Discussion}

Previous empirical studies have addressed antecedents of perceived control, such as causation and foreknowledge (Wortman, 1975), crowding and consumer choice (Hui \& Bateson, 1991) and spatial and human density (Rompay et al., 2008). The main contribution of this paper is to investigate the effect on consumers of an important and contemporary managerial strategy - co-production - on 
perceptions of control and satisfaction. This research thus draws on Skinner's (1996) conceptualization of perceived control to explain the effects of co-production on satisfaction. In this model, perceived control is viewed as resulting from behavioral control, referring here to coproduction, and from cognitive (i.e., information) and decisional (i.e. refund choice) controls. Findings from studies 1 and 2 strongly support Skinner's model of perceived control and confirm the power of perceived control in explaining the effects of co-production, in addition to information and choice, on consumer' satisfaction. These findings make it possible to positively answer the question posed in the introduction, regarding whether co-production could lead to higher consumer satisfaction by making them feel more in control during the purchase. Also, by deriving from two different contexts - services and goods - results of the present studies enhance the external validity of this research.

Variation in consumer's perceived control that is caused by co-production, information gain and refund choice exerts a considerable effect on satisfaction. The support for Hypothesis 1 suggests that co-production can induce more perceived control, since participating in the production process allows consumers to feel in control of the outcome product. The support for both Hypotheses 2 and 3 respectively reveals that both information and refund choice also contribute to such increase in consumers' perceived control. Taken together, these results are consistent with the tridimensional conceptualization of perceived control (Averill, 1973; Skinner, 1996). Note, though, that based on the $\mathrm{F}$ statistics the effect of co-production was stronger than the effects of refund choice or information gain.

The lack of interaction effects between co-production and information and co-production and choice denotes that combining two types of control, behavioral control through co-production with cognitive control, through information gain (study 1) or with decisional control, through consumer choice (study 2), does not make an individual perceive more control than having one of these types in isolation. This result is consistent with previous research showing that the effects of types of control are not cumulative. For instance, Mills and Krantz (1979) found in the context of blood-donation that giving both information about a stressful event (cognitive control) and the choice of which arm to be used for the donation (decisional control) was less effective at reducing stress than either type of control given alone.

The mediating role of perceived control was confirmed in both experiments. However, in the first experiment, the mediation was total, while in the second experiment, the mediation was only partial. This difference could be due the fact that whereas the first experiment had a service setting travel agency - where the financial and psychological costs may be high, the second had a product setting - a computer desk - in which the costs seem to be low. Therefore, control may have a more important role between co-production and satisfaction in cases of more important purchases, involving higher risks. Future research on this assumption is needed to better understand the role of coproduction in perceived control across different settings.

From a theoretical perspective, the results of these studies provide initial insight into the process through which co-production leads to satisfaction. Taken together, our results indicate that a key element in generating satisfaction through co-production is to instill a sense of control over the process. From a theoretical point of view, these results demonstrate that allowing consumers to coproduce can enhance a sense of control that generates satisfaction.

Several implications of interest to marketing practitioners also draw from the present research. As co-production leads to more perceived control, marketers can induce consumers' feelings of control by allowing them to participate in the production process. Giving consumers information about the product or service, or giving them choice, also represents for marketers the means to induce consumer's perceived control. As emphasized by the wide body of literature dealing with control, such feelings of control may result in a variety of positive outcomes, from emotions to behavioral responses, all of them being of interest to practitioners. However, if marketers provide information and choice in addition to co-production, the results of the two studies presented here show that this may not result in an increase in perceived control, nor in more satisfaction. 
Further, the results presented here do provide answers about the effects of co-production in the situation of complex co-production processes (comparing to a self-service situation, for instance). Marketers may thus be cautious to not provide too complex co-production processes that prevent consumers from feeling able to efficiently participate in the process. They may also keep in mind that the feeling of control induced by the co-production may only result in more satisfaction for consumers who actually desire to control the process. These promising topics for future studies are discussed below.

\section{Limitations and Further Research}

Although the results of the two experiments reported here consistently support the proposed framework, there are several points of caution that need to be addressed.

First, and despite significant results, the model and research reported here are intended as an initial step in describing the relationship between co-production, perceived control and satisfaction. It is likely that the model will be expanded and modified as more research is accumulated. Among variables that could be included in the model, potential moderators would be of interest to get a deeper understanding of the linkage between co-production, perceived control and satisfaction. To this regard, the examination of moderators that could explain the existence of situations in which co-production does not lead to more satisfaction is highly appealing. Indeed, the effects of changes in consumer perceived control are complex and may not lead only to positive outcomes (Burger, 1989). For instance, people who are given increased control over an event are also perceived as having increased responsibility for the subsequent outcomes of the event and thus experience increases in anxiety (Burger, Brown, \& Allen, 1983). Thus, among variables able to explain changes in the effects of perceived control in the co-production context, self-efficacy (Bandura, 1982) is of primary importance. How could co-production lead to more control and more satisfaction if consumers do not feel able to co-produce? This feeling of ability to actually perform the tasks derived from coproduction emerges from the literature as a potential moderator of the mediating role of perceived control on the linkage between co-production and satisfaction. Indeed, in the context of co-production, perceived control may result in more satisfaction only if the consumer feels the ability to co-produce. Such a proposition receives support from Ertimur (2008), who suggested that co-producers concerned with their own ability are more likely to experience a negative effect in response to increases in perceived control. Thus, further research may gain in including self-efficacy as a potential moderator explaining negative reactions to perceived control in a co-production context. In terms of experimental manipulation, self-efficacy could be manipulated through respondents' levels of familiarity with coproduction, or through the manipulations of false-feedback with respect to individual level of effectiveness toward performing some task, following Kidwell and Jewell (2010).

Second, further research dealing with the linkages between co-production, perceived control and consequent outcomes may include the extent to which consumers exhibit desire for control. Indeed, consumers may sometimes not want to feel in control over specific situations (Burger, 1985, 1989). Since such individual differences in the motivation for control may help account for variation in behavior (Burger \& Cooper, 1979), it may be argued that the effects of perceived control generated by co-production may not lead to positive outcomes for all consumers. It is likely that only consumers exhibiting a high degree of desire for control may exhibit positive outcomes to the control they feel from co-production.

Third, the study of when and why co-production leads to negative outcomes may gain in including the concept of learned helplessness (Seligman, 1975). Helplessness is the behavior manifested when an organism learns that an outcome and response are independent. Learned helplessness follows uncontrollable events and consists of three essential components: contingency, cognition, and behavior (Peterson, Maier, \& Seligman, 1993). Contingency refers to the degree of control of the individual, cognition refers to the subjective explanation of such a control (or lack of 
control), and behavior refers to the observable consequences of (non)contingency. Such a concept seems highly appealing and applicable to the context of co-production to explain whether consumers exhibit more or less satisfaction.

Future research should investigate whether when consumers are provided with the ability to coproduce and the necessary cognitive and behavioral resources to do so, they feel more contingency and consequently more satisfaction. Research should also test whether, on the contrary, when consumers are not able to co-produce and thus not able to perceive contingencies between their behavior and the outcomes, they feel less perceived control and less satisfaction.

Finally, we used a role-playing situation and student subjects in both experiments. Even though homogeneous samples are suitable for internal validity in experiments (Calder, Phillips, \& Tybout, 1981), caution should be taken before generalizing the findings. Future research could examine this phenomenon in other service settings, including purchases via internet, other populations (besides students) and natural consumer settings.

\section{Note}

\footnotetext{
${ }^{1}$ A previous version of this research was presented as an extended abstract at the 2011 North America's Association for Consumer Research Conference.
}

\section{References}

Ajzen, I. (1991). The theory of planned behavior. Organizational Behavior and Decision Human Processes, 50(2), 179-211. doi: 10.1016/0749-5978(91)90020-T

Ajzen, I. (2002). Perceived behavioral control, self-efficacy, locus of control, and the theory of planned behavior. Journal of Applied Social Psychology, 32(4), 665-683. doi: 10.1111/j.15591816.2002.tb00236.x

Averill, J. R. (1973). Personal control over aversive stimuli and its relationship to stress. Psychological Bulletin, 80(4), 286-303. doi: 10.1037/h0034845

Bandura, A. (1982). Self-efficacy mechanism in human agency. American Psychologist, 37(2), 122147. doi: 10.1037/0003-066X.37.2.122

Baron, R. M., \& Kenny, D. A. (1986). The moderator-mediator variable distinction in social psychological research: Conceptual, strategic, and statistical considerations. Journal of Personality and Social Psychology, 51(6), 1173-1182. doi: 10.1037/0022-3514.51.6.1173

Bateson, J. E. G. (1985). Perceived control and the service encounter. In J. A. Czepiel, M. R. Solomon, \& C. F. Surprenant (Eds.), The service encounter (pp. 67-82). Massachusetts / Toronto: Lexington Books.

Bateson, J. E. G., \& Hui, M. K. (1992). The ecological validity of photographic slides and videotapes in simulating the service setting. Journal of Consumer Research, 19(2), 271-281. doi: $10.1086 / 209301$

Bateson, J. E. G., \& Langeard, E. (1982). Consumer uses of common dimensions in the appraisal of services. In A. Mitchell \& A. Abor (Eds.), Advances in consumer research (pp. 173-176). Provo, UT: Association for Consumer Research. 
Bendapudi, N., \& Leone, R. P. (2003). Psychological implications of customer participation in coproduction. Journal of Marketing, 67(1), 14-28. doi: 10.1509/jmkg.67.1.14.18592

Bitner, M. J., Faranda, W. T., Hubbert, A. R., \& Zeithaml, V. A. (1997). Customer contributions and roles in service delivery. International Journal of Service Industry Management, 8(3), 193-205. doi: $10.1108 / 09564239710185398$

Botti, S., Broniarczyk S., Häubl G., Hill R., Huang Y., Kahn B., Kopalle P., Lehmann D., Urbany J., \& Wansink B. (2008). Choice under restrictions. Marketing Letters, 19(3/4), 183-199. doi: $10.1007 / \mathrm{s} 11002-008-9035-4$

Botti, S., \& McGill, A. L. (2006). When choosing is not deciding: the effect of perceived responsibility on satisfaction. Journal of Consumer Research, 33(2), 211-219.

Burger, J. M. (1985). Desire for control and achievement-related behaviors. Journal of Personality and Social Psychology, 48(6), 1520-1533. doi: 10.1037/0022-3514.48.6.1520

Burger, J. M. (1989). Negative reactions to increases in perceived personal control. Journal of Personality and Social Psychology, 56(2), 246-256. doi: 10.1037/0022-3514.56.2.246

Burger, J. M., \& Arkin, R. M. (1980). Prediction, control, and learned helplessness. Journal of Personality and Social Psychology, 38(3), 482-491. doi: 10.1037/0022-3514.38.3.482

Burger, J. M., Brown, R., \& Allen, C. A. (1983). Negative reactions to personal control. Journal of Social and Clinical Psychology, 1(4), 322-342. doi: 10.1521/jscp.1983.1.4.322

Burger, J. M., \& Cooper H. M. (1979). The desirability of control. Motivation and Emotion, 3(4), 381393. doi: $10.1007 / \mathrm{BF} 00994052$

Calder, B. J., Phillips, L. W., \& Tybout, A. M. (1981). Designing research for application. Journal of Consumer Research, 8(2), 197-207. doi: 10.1086/208856

Challagalla, G. N., \& Shervani, T. A. (1996). Dimensions and types of supervisory control: effects on salesperson performance and satisfaction. Journal of Marketing, 60(1), 89-105. doi: $10.2307 / 1251890$

Chang, C. C. (2008). Choice, perceived control, and customer satisfaction: The psychology of online service recovery. Cyberpsychology \& Behavior, 11(3), 321-328. doi: 10.1089/cpb.2007.0059

Collier, J. E., \& Sherrell, D. L. (2010). Examining the influence of control and convenience in a selfservice setting. Journal of the Academy of Marketing Science, 38(4), 490-509. doi: 10.1007/s11747-009-0179-4

Cornelius, R., \& Averill, J. R. (1980). The influence of various types of control on psychophysiological stress reactions. Journal of Research in Personality, 14(4), 503-517. doi: 10.1016/0092-6566(80)90008-2

Dabholkar, P. A. (1996). Consumer evaluations of new technology-based self-service options: an investigation of alternative models of service quality. International Journal of Research in Marketing, 13(1), 29-51. doi: 10.1016/0167-8116(95)00027-5

DeCharms, R. (1968). Personal causation. New York, NY: Academic Press.

Dellaert, B. G. C., \& Dabholkar, P. A. (2009). Increasing the attractiveness of mass customization: the role of complementary on-line services and range of options. International Journal of Electronic Commerce, 13(3), 43-70. doi: 10.2753/JEC1086-4415130302 
Dholakia, N., Zwick, D., \& Denegri-Knott, J. (2010). Technology, consumers, and marketing theory. In P. Maclaran, M. Saren, B. Stern, \& M. Tadajewsky (Eds.), The SAGE handbook of marketing theory (pp. 494-511). London: Sage.

Dong, B., Evans, K. R., \& Zou, S. (2011). What if a co-produced service fails? An investigation of customer participation in service recovery. Proceedings of the AMA Summer Marketing Educators' Conference, San Francisco, CA, United States of America.

Ertimur, B. (2008). The role of perceived control in co-production. In S. Borghini, M. A. McGrath, \& C. Otnes (Eds.), European advances in consumer research (pp. 334-335). Duluth, MN: Association for Consumer Research.

Etgar, M. (2008). A descriptive model of the consumer co-production process. Journal of the Academy of Marketing Science, 36(1), 97-108. doi: 10.1007/s11747-007-0061-1

Faranda, W. T. (2001). A scale to measure the cognitive control form of perceived control: construction and preliminary assessment. Psychology \& Marketing, 18(12), 1259-1281. doi: $10.1002 /$ mar. 1052

Glass, D. C., \& Singer J. E. (1972). Urban stress: experiments on noise and social stressors. New York, NY: Academic Press.

Golder, P. N., Mitra, D., \& Moorman, C. (2012). What is quality? An integrative framework of processes and states. Journal of Marketing, 76(4), 1-23. doi: 10.1509/jm.09.0416

Greenberger, D., Strasser, S., Cummings, L., \& Dunhan, R. (1989). The impact of personal control on performance and satisfaction. Organizational Behaviour and Human Decision Processes, 43(1), 29-51. doi: 10.1016/0749-5978(89)90056-3

Hayes, A. F. (2009). Beyond Baron and Kenny: statistical mediation analysis in the new millennium. Communication Monographs, 76(4), 408-420. doi: 10.1080/03637750903310360

Holt, D. B. (1995). How consumers consume: a typology of consumption practices. Journal of Consumer Research, 22(1), 1-16. doi: 10.1086/209431

Hui, M. K., \& Bateson, J. E. G. (1991). Perceived control and the effects of crowding and consumer choice on the service experience. Journal of Consumer Research, 18(2), 174-184. doi: $10.2307 / 2489553$

Hunt, D., Oneto, S. G., \& Varca, P. (2010). Satisfaction in the context of customer co-production. Proceedings of the Association for Consumer Research Conference, Duluth, MN, United States of America, 38.

Kang, H., Hahn, M., Fortin, D. R., Hyun, Y. J., \& Eom, Y. (2006). Effects of perceived behavioral control on the consumer usage intention. Psychology \& Marketing, 23(10), 841-864. doi: 10.1002/mar.20136

Kidwell, B., \& Jewell, R. D. (2010). The motivational impact of perceived control on behavioral intentions. Journal of Applied Social Psychology, 40(9), 2407-2433. doi: 10.1111/j.15591816.2010.00664.X

Langer, E. J. (1975). The illusion of control. Journal of Personality and Social Psychology, 32(2), 311-328. doi: 10.1037/0022-3514.32.2.311

Langer, E. J., \& Saegert, S., (1977). Crowding and cognitive control. Journal of Personality and Social Psychology, 35(3), 175-182. doi: 10.1037/0022-3514.35.3.175

Lazarus, R. S., \& Folkman, S. (1984). Stress, appraisal and coping. New York, NY: Springer. 
Lee, J. (2012). Components of medical service users' dissatisfaction: a perceived control perspective. International Journal of Management and Marketing Research, 5(2), 53-63.

Liechty, J., Ramaswamy, V., \& Cohen, S. H. (2001). Choice menus for mass customization: an experimental approach for analyzing customer demand with an application to a web-based information service. Journal of Marketing Research, 38(2), 183-196. doi: 10.1509/jmkr.38.2.183.18849

Lunardo, R., \& Mbengue, A. (2009). Perceived control and shopping behavior: the moderating role of the level of utilitarian motivational orientation. Journal of Retailing and Consumer Services 16(6), 434-441. doi: 10.1016/j.jretconser.2009.06.004

Lusch, R. F., \& Vargo, S. L. (2006). The service-dominant logic of marketing: dialog, debate, and directions. New York, NY: M. S. Sharpe.

Lusch, R. F., Vargo, S. L., \& O’Brien, M. (2007). Competing through service: insights from servicedominant logic. Journal of Retailing, 83(1), 5-18. doi: 10.1016/j.jretai.2006.10.002

Mathur, A. (1998). Examining trying as a mediator and control as a moderator of intention-behavior relationship. Psychology \& Marketing, 15(3), 241-259. doi: 10.1002/(SICI)15206793(199805)15:3<241::AID-MAR3>3.0.CO;2-A

Mehrabian, A., \& Russell, J. A. (1974). An approach to environmental psychology. Cambridge, MA: MIT Press.

Meuter, M. L., Bitner, M. J., Ostrom, A. L., \& Brown, S. W. (2005). Choosing among alternative service delivery modes: an investigation of customer trial of self-service technologies. Journal of Marketing, 69(2), 61-83. doi :10.1509/jmkg.69.2.61.60759

Mills, R. T., \& Krantz, D. S. (1979). Information, choice, and reactions to stress: A field experiment in a blood bank with laboratory analogue. Journal of Personality and Social Psychology, 37(4), 608-620. doi: 10.1037/0022-3514.37.4.608

Namasivayam, K. (2004). Action control, proxy control and consumers' evaluations of the service exchange. Psychology \& Marketing, 21(6), 463-480. doi: 10.1002/mar.20014

Namasivayam, K., \& Hinkin, T. R. (2003). The customer's role in the service encounter: the effects of control and fairness. Cornell Hotel and Restaurant Administration Quarterly, 44(3), 26-36. doi: 10.1016/S0010-8804(03)90267-

Nysveen, H., Pedersen, P. E., \& Thorbjornsen, H. (2005). Intentions to use mobile services: antecedents and cross-service comparisons. Journal of the Academy of Marketing Science, 33(3), 330-346. doi: 10.1177/0092070305276149

Oliver, R. L., \& Anderson, E. (1994). An empirical test of the consequences of behavior and outcomebased Sales control systems. Journal of Marketing, 58(4), 53-67.

Peppers, D., \& Rogers, M. (1993). The one to one future: building relationships one customer at a time. New York: Doubleday Business.

Peterson, C., Maier, S. F., \& Seligman, M. (1993). Learned helplessness: a theory for the age of personal control. New-York (NY): Oxford University Press.

Prahalad, C. K., \& Ramaswamy, V. (2004). Co-creation experiences: the next practice in value creation. Journal of Interactive Marketing, 18(3), 5-14. doi: 10.1002/dir.20015 
Preacher, K. J., \& Hayes, A. F. (2008). Asymptotic and resampling strategies for assessing and comparing indirect effects in multiple mediator models. Behavior Research Methods, 40(3), 879-891. doi: 10.3758/BRM.40.3.879

Rodin, J. (1990). Control by any other name: definitions, concepts, and processes. In J. Rodin, C. Schooler, \& K. W. Schaie (Eds.), Self-directedness: cause and effects throughout the life course (pp. 1-15). Hillsdale, NJ: Erlbaum.

Rompay, T. J. L. van, Galetzka, M., Pruyn, A. T. H., \& Garcia, J. M. (2008). Human and spatial dimensions of retail density: revisiting the role of perceived control. Psychology \& Marketing, 25(4), 319-335. doi: 10.1002/mar.20211

Rotter, J. B. (1966). Generalized expectancies for internal versus external control of reinforcement. Psychological Monographs, 80(1), 1-28. doi: 10.1037/h0092976

Sawyer, A. G. (1975). Demand artifacts in laboratory experiments in consumer research. Journal of Consumer Research, 1(4), 20-30.

Seligman, M. E. P. (1975). Helplessness: on depression, development, and death. San Francisco: Freeman.

Skinner, E. A. (1995). Perceived control, motivation, and coping. London: Sage Publication.

Skinner, E. A. (1996). A guide to constructs of control. Journal of Personality and Social Psychology, 71(3), 549-570. doi: 10.1037/0022-3514.71.3.549

Sprott, D. E., Brumbaugh, A. M., \& Miyazaki, A. D. (2001). Motivation and ability as predictors of play behavior in state-sponsored lotteries: an empirical assessment of psychological control. Psychology \& Marketing, 18(9), 973-983. doi: 10.1002/mar.1038

Staub, E., Tursky, B., \& Schwartz, G. E. (1971). Self-control and predictability: Their effects on reactions to aversive stimulation. Journal of Personality and Social Psychology, 18(2), 157-162. doi: $10.1037 / \mathrm{h} 0030851$

Thompson, S. C. (1981). Will it hurt less if I can control it? A complex answer to a simple question. Psychological Bulletin, 90(1), 89-101.

Troye, S. V., \& Supphellen, M. (2012). Consumer participation in coproduction: "I made it myself" effects on consumers' sensory perceptions and evaluations of outcome and input product. Journal of Marketing, 76(2), 33-46. doi :10.1509/jm.10.0205

Van Raaij, W. F., \& Pruyn, A. T. H. (1998). Customer control and evaluation of service validity and reliability. Psychology \& Marketing, 15(8), 811-832. doi: 10.1002/(SICI)15206793(199812)15:8<811::AID-MAR6>3.0.CO;2-8

Vargo, S. L., \& Lusch, R. F. (2008). Service-dominant logic: continuing the evolution. Journal of the Academy of Marketing Science, 36(1), 1-10. doi: 10.1007/s11747-007-0069-6

Verhoef, P. C. (2003). Understanding the effect of customer relationship management efforts on customer retention and customer share development. Journal of Marketing, 67(4), 30-45. doi: 10.1509/jmkg.67.4.30.18685

Ward, J. C., \& Barnes, J. W. (2001). Control and affect: the influence of feeling in control of the retail environment on affect, involvement, attitude, and behavior. Journal of Business Research, 54(2), 139-144. 
Wathieu, L., Brenner, L., Carmon, Z., Chattopadhyay, A., Wertenbroch, K., Drolet, A., Gourville, J., Muthukrishnan, A. V., Novemsky, N., Ratner, R., \& Wu, G. (2002). Consumer control and empowerment: a primer. Marketing Letters, 13(3), 297-305. doi: 10.1023/A:1020311914022

Wikström, S. (1996). The customer as co-producer. European Journal of Marketing, 30(4), 6-19. doi: $10.1108 / 03090569610118803$

Witt, L. A., Andrews, M. C., \& Kacmar, K. M. (2000). The role of participation in decision-making in the organizational politics-job satisfaction relationship. Human Relations, 53(3), 341-358. doi: 10.1177/0018726700533003

Woodruff, R. B., Cadotte, E. R., \& Jenkins, R. L. (1983). Modeling consumer satisfaction process using experience-based norms. Journal of Marketing Research, 20(3), 296-304.

Wortman, C. B. (1975). Some determinants of perceived control. Journal of Personality and Social Psychology, 31(2), 282-294. doi: 10.1037/h0076305

Zhao, X., Lynch, J. G. Jr., \& Chen, Q. (2010). Reconsidering Baron and Kenny: Myths and truths about mediation analysis. Journal of Consumer Research, 37(2), 197-206. doi: 10.1086/651257 